\title{
Improvement of "Bouncy Gait" in Lance-Adams Syndrome with Perampanel
}

\author{
Shen-Yang Lim ${ }^{1}$, Dushyanth Babu Jasti ${ }^{2}$, Ai Huey Tan ${ }^{1}$ \\ 1. Division of Neurology and the Mah Pooi Soo \& Tan Chin Nam Centre for Parkinson's \& Related Disorders, Faculty of \\ Medicine, University of Malaya, Kuala Lumpur, MYS 2. Division of Neurology, Kasturba Medical College, Manipal, IND
}

Corresponding author: Shen-Yang Lim, limshenyang@gmail.com

\begin{abstract}
Lance-Adams syndrome (LAS) is chronic post-hypoxic myoclonus that is often associated with sudden lapses in muscle tone (negative myoclonus) in the legs, causing a disabling "bouncy gait." Given its relative rarity, there are no controlled treatment studies of LAS. The majority of cases require polypharmacy management, with an incomplete response. "Bouncy gait," in particular, is notoriously medication-refractory. Here, we report a patient with long-standing LAS who improved markedly when low-dose perampanel was added to his existing treatment regime consisting of clonazepam, levetiracetam, sodium valproate, and acetazolamide.
\end{abstract}

Categories: Internal Medicine, Neurology, Physical Medicine \& Rehabilitation

Keywords: lance-adams syndrome, perampanel, myoclonus, negative myoclonus, bouncy gait

\section{Introduction}

Lance-Adams syndrome (LAS) is chronic post-hypoxic myoclonus with onset days to weeks after a hypoxic episode, when the patient has regained consciousness [1]. The myoclonus is typically multifocal, worse with action, and associated with sudden lapses in muscle tone in the legs, causing a "bouncy gait" [1]. Additional features may include cognitive impairment, seizures, dysarthria, and ataxia [1]. Given its relative rarity, there are no controlled treatment studies of LAS. The majority of cases require polypharmacy management, with an incomplete response. "Bouncy gait," in particular, is notoriously medication-refractory [2]. Here, we report a patient with long-standing LAS who improved markedly when low-dose perampanel was added to his existing treatment regime.

Received 01/10/2020 Review began 01/11/2020 Review ended 01/16/2020 Published 01/25/2020

\section{() Copyright 2020}

Lim et al. This is an open access article distributed under the terms of the Creative Commons Attribution License CC-BY 3.0., which permits unrestricted use, distribution, and reproduction in any medium, provided the original author and source are credited.

\section{Case Presentation}

A 63-year-old Malaysian man of Chinese ethnicity underwent cardiac bypass surgery in 2013 for triplevessel disease, which was complicated postoperatively by cardiac arrest resulting in hypoxic coma. He was hospitalized for three months, of which one-and-a-half months was in the intensive care unit. During his recovery, the patient experienced jerks involving the whole body and difficulty walking. There was also significant cognitive impairment. Epileptic seizures occurred during his hospitalization but not after discharge. He was treated with twice-daily clonazepam $0.5 \mathrm{mg}$, levetiracetam $500 \mathrm{mg}$, and sodium valproate $200 \mathrm{mg}$.

He was referred to our center in November 2017 from the rehabilitation physician with a diagnosis of "ataxia" causing gait difficulty as his main problem. On examination, there was an obvious "bouncy gait," requiring close supervision and, frequently, assistance to walk just several feet within the consulting room; gait was very hesitant and wide-based with an obvious tendency to falls. There was positive action myoclonus in the arms when performing the finger-to-nose test, more obvious on the left (mild-to-moderate amplitude) but no significant myoclonus at rest nor with the arms outstretched (and no asterixis). There was no significant stimulus-sensitivity to touch. Eye movements were normal, with mild-to-moderately slurred speech. There were no other features of cerebellar ataxia, Parkinsonism, or dystonia. The Montreal Cognitive Assessment (MoCA) score was 17/30. Brain MRI was normal. Lance-Adams syndrome (LAS) was diagnosed. Acetazolamide $250 \mathrm{mg}$ bid was added, without significant improvement. We have in our patient medical records three video recordings taken, with the patient's written permission, over approximately two years, showing the relative stability of the patient's condition. These are available upon request from the corresponding author.

Due to ongoing gait difficulty and based on emerging reports of perampanel use in myoclonic disorders [3], we added perampanel in August 2019. Improvement occurred within the first week on $2 \mathrm{mg} / \mathrm{d}$, with further improvement on $4 \mathrm{mg} / \mathrm{d}$. A home video sent to us by the patient's family showed that his gait was obviously improved. He was able to walk independently, without a walking aid, at home and in a shopping center, with no "bouncy gait" evident. There were no adverse effects, and the benefit has been sustained at least until the time of writing of this report (October 2019). 


\section{Cureus}

\section{Discussion}

Myoclonus in LAS is thought to be most commonly cortical in origin and may relate to abnormal gammaaminobutyric acid (GABA) and serotonin neurotransmission in the brain [1]. There are no well-defined guidelines for treatment in LAS. Anti-epileptic drugs (AED) such as valproic acid, clonazepam, and/or piracetam/levetiracetam are commonly used, but treatment response is often unsatisfactory [1-2]; thus, there is need for new therapeutic options.

Perampanel is a recently introduced AED that antagonizes post-synaptic alpha-amino-3-hydroxy-5-methyl4-isoxazolepropionic acid (AMPA) receptors. It is effective for seizures and myoclonus in different types of epilepsies, including progressive myoclonic epilepsies [3-4], with some patients regaining ambulatory capacity post-treatment [2]. Sedation, dizziness, anxiety, and irritability appear to be the most common adverse effects [3-4]. To our knowledge, there has been only one fully published case report [3] describing an improvement of myoclonus in LAS using perampanel (Table 1) [3,5-7]. A recent electrophysiological study reported that improvement in cortical myoclonus with perampanel correlated with improvements in the parameters of giant somatosensory-evoked potentials [7]. 


\section{Cureus}

\begin{tabular}{|c|c|c|c|c|c|}
\hline Variable & $\begin{array}{l}\text { Steinhoff et al. Epilepsy } \\
\text { Behav Case Rep } 2016 \\
\text { (Germany) [3] }\end{array}$ & $\begin{array}{l}\text { Lazaro Lopez et al. } \\
\text { Eur J Hospital } \\
\text { Pharmacy } 2017 \\
\text { (Spain) (Abstract } \\
\text { only) [5] }\end{array}$ & $\begin{array}{l}\text { Yelden et al. Brain Injury } \\
2019 \text { (UK) (Abstract only) } \\
\text { [6] }\end{array}$ & $\begin{array}{l}\text { Oi et al. Clin Neurophysiol } \\
2019 \text { (Japan) [7] }\end{array}$ & $\begin{array}{l}\text { Present Case } \\
\text { Report } \\
\text { (Malaysia) }\end{array}$ \\
\hline $\begin{array}{l}\text { Age of } \\
\text { patient } \\
\text { (years) }\end{array}$ & 36 & 35 & \#1:69; \#2: 37 & \#1: 47; \#2: 31 & 63 \\
\hline Gender & M & M & \#1: M, \#2: F & Both M & M \\
\hline $\begin{array}{l}\text { Antecedent } \\
\text { event }\end{array}$ & $\begin{array}{l}\text { Cardiac arrest due to } \\
\text { Brugada syndrome }\end{array}$ & $\begin{array}{l}3 \text { consecutive cardiac } \\
\text { arrests }\end{array}$ & $\begin{array}{l}\# 1 \text { : Severe pneumonia; \#2: } \\
\text { Accidental decannulation } \\
\text { of the tracheostomy tube }\end{array}$ & NA & $\begin{array}{l}\text { Cardiac arrest } \\
\text { in the } \\
\text { postoperative } \\
\text { period } \\
\text { following } \\
\text { cardiac } \\
\text { surgery }\end{array}$ \\
\hline $\begin{array}{l}\text { Duration of } \\
\text { LAS prior to } \\
\text { PER (years) }\end{array}$ & 1 & NA & NA & NA & 6 \\
\hline $\begin{array}{l}\text { Medication } \\
\text { treatment } \\
\text { prior to PER } \\
(\mathrm{mg} / \mathrm{d})\end{array}$ & $\begin{array}{l}\text { LEV (2000); VAL (1500); } \\
\text { CLON (2); PIR (7,600); } \\
\text { LAC (100), treatments } \\
\text { were "in vain" }\end{array}$ & $\begin{array}{l}\text { LEV; VAL; Propofol; } \\
\text { Sodium thiopental; } \\
\text { PIR; ZNS; Clonidine; } \\
\text { Sodium oxybate; 5- } \\
\text { HT; Gabapentin }\end{array}$ & $\begin{array}{l}\text { LEV; VAL; CLON at "high" } \\
\text { doses - patients said to } \\
\text { be "resistant" }\end{array}$ & $\begin{array}{l}\text { \#1: LEV; CLON; PRIM; CBZ; } \\
\text { PIR \#2: CLON; PIR }\end{array}$ & $\begin{array}{l}\text { LEV (1000); } \\
\text { VAL (400); } \\
\text { CLON (1); } \\
\text { ACET (250) }\end{array}$ \\
\hline $\begin{array}{l}\text { Perampanel } \\
\text { dose (mg/d) }\end{array}$ & $\begin{array}{l}2 \mathrm{mg} / \mathrm{d} \text { for } 1^{\text {st }} 3 \text { days, then } \\
4 \mathrm{mg} / \mathrm{d}\end{array}$ & 24 & NA & \#1:10; \#2: 4 & $\begin{array}{l}2 \mathrm{mg} / \mathrm{d} \text { for } 1^{\text {st }} \\
\text { week, then } \\
4 \mathrm{mg} / \mathrm{d}\end{array}$ \\
\hline $\begin{array}{l}\text { Clinical } \\
\text { response }\end{array}$ & $\begin{array}{l}\text { Almost complete } \\
\text { cessation of myoclonic } \\
\text { jerks at } 4 \mathrm{mg} \text {, but no } \\
\text { mention of gait } \\
\text { improvement } \\
\text { (wheelchair-bound) }\end{array}$ & $\begin{array}{l}\text { "Controlled" the } \\
\text { myoclonus }\end{array}$ & $\begin{array}{l}\# 1: \text { Myoclonus greatly } \\
\text { improved with improved } \\
\text { function; \#2: Function } \\
\text { improved including } \\
\text { ambulation and speech }\end{array}$ & $\begin{array}{l}\# 1: \text { Myoclonus improved from } \\
\text { marked to severe; \#2: No } \\
\text { improvement in myoclonus } \\
\text { (remained moderate); Both } \\
\text { improved in ADLs }\end{array}$ & \\
\hline $\begin{array}{l}\text { Drugs able } \\
\text { to be } \\
\text { reduced or } \\
\text { discontinued }\end{array}$ & PIR and LAC stopped & $\begin{array}{l}\text { All other medications } \\
\text { besides LEV, } \\
\text { gabapentin, PER, and } \\
\text { risperidone were } \\
\text { stopped }\end{array}$ & $\begin{array}{l}\text { \#1: CLON reduced; \#2: } \\
\text { CLON and VAL stopped }\end{array}$ & NA & Not yet \\
\hline $\begin{array}{l}\text { Follow-up } \\
\text { period }\end{array}$ & $>4$ weeks & NA & NA & NA & 6 weeks \\
\hline $\begin{array}{l}\text { Adverse } \\
\text { effects }\end{array}$ & $\begin{array}{l}\text { Somnolence, but this } \\
\text { improved over time }\end{array}$ & $\begin{array}{l}\text { "Behavioural } \\
\text { disorders", requiring } \\
\text { risperidone treatment }\end{array}$ & NA & $\begin{array}{l}\text { \#1: None; \#2: Dizziness and } \\
\text { palpitation }\end{array}$ & No \\
\hline
\end{tabular}

\section{TABLE 1: Case reports of patients with Lance-Adams syndrome treated with perampanel}

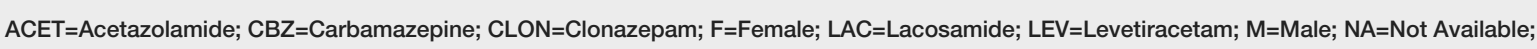
$\mathrm{PER}=$ Perampanel; PIR=Piracetam; PRIM=Primidone; UK=United Kingdom; VAL=Sodium valproate; ZNS=Zonisamide; 5-HT= 5-hydroxytryptophan

\section{Conclusions}

In conclusion, we observed a remarkable improvement of LAS with low-dose perampanel treatment, which was also well-tolerated. This agent warrants further study in larger numbers of patients and over longer durations of follow-up, to confirm long-term efficacy and safety for treating LAS. All cases reported thus far have been treated with multiple medications before the introduction of perampanel, and further research should also determine if perampanel can be effectively employed earlier in the treatment course of LAS. 


\section{Additional Information}

\section{Disclosures}

Human subjects: Consent was obtained by all participants in this study. Conflicts of interest: In compliance with the ICMJE uniform disclosure form, all authors declare the following: Payment/services info: All authors have declared that no financial support was received from any organization for the submitted work. Financial relationships: All authors have declared that they have no financial relationships at present or within the previous three years with any organizations that might have an interest in the submitted work. Other relationships: All authors have declared that there are no other relationships or activities that could appear to have influenced the submitted work.

\section{References}

1. Gupta HV, Caviness JN: Post-hypoxic myoclonus: current concepts, neurophysiology and treatment. Tremor Other Hyperkinet Mov (N Y). 2016, 6:409. 10.7916/D89C6XM4

2. Stahl CM, Frucht SJ: An update on myoclonus management. Expert Rev Neurother. 2019, 19:325-331. 10.1080/14737175.2019.1592676

3. Steinhoff B J, Bacher M, Kurth C, Staack AM, Kornmeier R: Add-on perampanel in Lance Adams syndrome. Epilepsy Behav Case Rep. 2016, 6:28-29. 10.1016/j.ebcr.2016.05.001

4. Canafoglia L, Barbella G, Ferlazzo E, et al.: An Italian multicentre study of perampanel in progressive myoclonus epilepsies. Epilepsy Res. 2019, 156:106191. 10.1016/j.eplepsyres.2019.106191

5. Lazaro López E, Jalon Urbina MM, Sánchez AP, et al.: D1-096 Refractory Lance-Adams syndrome: pharmacotherapy management and iatrogenic complications. Eur J Hospital Pharmacy. 2017, 24:A156. 10.1136/ejhpharm-2017-000640.343

6. Yelden K, Rendell L, Vardy L, Rose A, Crilly S, Merrison K: Treatment of refractory myoclonus with perampanel in Lance Adams syndrome: a report of two cases. Accepted abstracts from the International Brain Injury Association's 13th World Congress on Brain Injury. Brain Inj. 2019, 33:1-337. 10.1080/02699052.2019.1608749

7. Oi K, Neshige S, Hitomi T, et al.: Low-dose perampanel improves refractory cortical myoclonus by the dispersed and suppressed paroxysmal depolarization shifts in the sensorimotor cortex. Clin Neurophysiol. 2019, 130:1804-1812. 10.1016/j.clinph.2019.07.006 